\title{
A PLEA OF DOUBLE JEOPARDY BY ACCUSED EMPLOYERS: ARE THERE LIMITS?
}

\author{
Fareed Moosa \\ BProc LLB LLM LLD \\ Associate Professor, Department of Mercantile \\ and Labour Law, University of the \\ Western Cape
}

\section{SUMMARY}

The rule against double jeopardy entails that, generally, a person cannot be charged more than once for the same, or substantially the same, offence or misconduct in respect of which he or she has been convicted or acquitted. Under the Constitution of the Republic of South Africa, 1996, this rule is part of an accused's right to a fair trial. This article shows that every employer prosecuted for allegedly not complying with either employees' tax obligations in the Fourth Schedule of the Income Tax Act 58 of 1962 , or for an offence at common law, is entitled to raise the procedural defence of double jeopardy. This article argues that the recent judgment in Grayston Technology Investment (Pty) $L t d v S$ is authority for the proposition that, in any such prosecution, an accused employer may invoke double jeopardy, even if the prior punishment or acquittal stems from non-criminal proceedings under the Tax Administration Act 28 of 2011 before the Tax Court or the Tax Board. A key hypothesis of this article is the argument that double jeopardy ought not to be applied as an inflexible procedural rule in every instance. This is because such an approach would lead to the undesirable result of undermining the Legislature's objective in catering for criminal and civil sanctions in respect of certain violations of fiscal legislation. No hard-andfast rules can be laid down in advance as to when double jeopardy may be successfully invoked. Each case needs to be decided on its own facts. It is contended that when a court decides whether to uphold a double-jeopardy defence, it must strike an equitable balance between, on the one hand, the accused employer's fundamental right to a fair trial and, on the other, society's legitimate interest in ensuring that taxpayers comply with their tax obligations on pain of adequate punishment for non-compliance.

Are there limits to the plea of double jeopardy by accused employers?

"To me at least, it is hard to see why the double jeopardy principle should apply when the state wants to chop off my toes, but not when it seeks to slit my nose, or brand my skin, or gouge my ears, or flay my back."1

\section{INTRODUCTION}

The South African Revenue Service (SARS) is established by section 2 of the South African Revenue Service $\mathrm{Act}^{2}$ (SARSA) "as an organ of state

\footnotetext{
Amar "Double Jeopardy Law Made Simple" 1997106 Yale Law Journal 18071811.
} 
within the public administration, but as an institution outside the public service". Its objective is "the efficient and effective collection of revenue". ${ }^{3}$ In this context, revenue means "income derived from taxes, duties, levies, fees, charges, additional tax and any other moneys imposed in terms of legislation, including penalties and interest in connection with such moneys". ${ }^{4}$ SARS is obliged to "secure the efficient and effective, and widest possible enforcement of", ${ }^{5}$ inter alia, the Income Tax Act ${ }^{6}$ (ITA). As an organ of state, SARS is bound by the Bill of Rights (the BoR) in terms of section $8(1)$ of the Constitution of the Republic of South Africa, 1996 (the Constitution) to respect taxpayers' fundamental rights. ${ }^{7}$ The Tax Administration Act ${ }^{8}$ (TAA) confers on SARS a formidable arsenal of powers that include, inter alia, an authority to impose penalties for non-compliance with a "tax Act" (as defined). ${ }^{9}$ Broadly speaking, these are administrative non-compliance penalties ${ }^{10}$ and understatement penalties. ${ }^{11} \mathrm{~A}$ defaulting taxpayer may also be prosecuted for an offence under Chapter 17 of the TAA, or an offence at common law. ${ }^{12}$

\section{PROBLEM STATEMENT AND OBJECTIVE OF THE ARTICLE}

In accordance with section 5(1) of the ITA, the Fourth Schedule thereof creates a framework that regulates the collection of employees' tax, colloquially referred to as Pay As You Earn (PAYE), and matters related thereto. In terms of paragraph 2(1) of the Fourth Schedule, an "employer" (as defined) ${ }^{13}$ who qualifies as a "resident" (as defined) ${ }^{14}$ for income tax

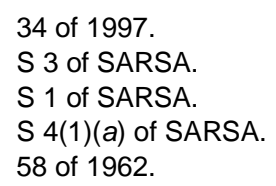

Although the BoR does not expressly refer to taxpayers as a class of beneficiary, courts have recognised their entitlement to fundamental rights. See, for e.g., Metcash Trading Ltd $v$ Commissioner, South African Revenue Service (CSARS) 2001 (1) SA 1109 (CC) (right of access to court in s 34); First National Bank of SA Ltd t/a Wesbank v CSARS: First National Bank of SA Ltd v Minister of Finance 2002 (4) SA 768 (CC) (right to property); and Gaertner $v$ Minister of Finance 2014 (1) SA 442 (CC) (right to privacy).

828 of 2011.

9 The TAA (s 1) defines "tax Act" to mean "this Act or an Act, or portion of an Act, referred to in section 4 of the SARS Act, excluding Customs and Excise legislation".

10 See s 208 of the TAA for the definition of "administrative non-compliance penalty". S 209(b) provides that such penalties are to be "imposed impartially, consistently, and proportionately to the seriousness and duration of the non-compliance".

11 S 221 of the TAA defines "understatement" to mean "any prejudice to SARS or the fiscus as a result of-(a) failure to submit a return required under a tax Act or by the Commissioner; (b) an omission from a return; (c) an incorrect statement in a return; (d) if no return is required, the failure to pay the correct amount of 'tax'; or (e) an impermissible avoidance arrangement". SARS must show that a taxpayer committed the offending conduct and that it caused prejudice. See Purlish Holdings (Pty) Ltd v CSARS 81 SATC 204 par 20. Also, see ITC 193482 SATC 457 par 26-27, 32-36.

12 See, for e.g., Director of Public Prosecutions, Western Cape v Parker 2015 (4) SA 28 (SCA).

13 "Employer" is defined in par 1 of the Fourth Schedule of the ITA to mean "any person (excluding any person not acting as a principal, but including any person acting in a 
purposes, irrespective of whether or not it is registered for PAYE under paragraph 15 of the Fourth Schedule, and

"who pays or becomes liable to pay any amount by way of remuneration ${ }^{15}$ to any employee ${ }^{16}$ shall, unless the Commissioner has granted authority to the contrary, ${ }^{17}$ deduct or $^{18}$ withhold from that amount, or, where that amount constitutes any lump sum contemplated in paragraph 2(1)(b) of the Second Schedule, deduct from the employee's benefit or minimum individual reserve as contemplated in that paragraph, by way of employees' tax an amount which shall be determined as provided in paragraph 9,10 or 11 or section 95 of the Tax Administration Act, whichever is applicable, in respect of the liability for normal tax of that employee, ... and shall, subject to the Employment Tax Incentive Act, 2013, pay the amount so deducted or withheld to the Commissioner within seven days after the end of the month during which the amount was deducted or withheld".

Accordingly, an employer is a "withholding agent"19 of employees' tax and is obliged to pay it to SARS by the seventh day of each calendar month. This PAYE is remitted together with an EMP201 form on which an employer discloses all relevant information pertaining to the computation of the PAYE. ${ }^{20}$ The legislature's use of the word "shall" when it imposed the duty on an employer to "deduct or withhold" PAYE emphasises the mandatory character of the obligation in question. Thus, compliance with paragraph 2(1) is compulsory. ${ }^{21}$ The imperative nature of this duty is further bolstered by,

fiduciary capacity or in his capacity as a trustee in an insolvent estate, an executor or an administrator of a benefit fund, pension fund, pension preservation fund, provident fund, provident preservation fund, retirement annuity fund or any other fund) who pays or is liable to pay to any person any amount by way of remuneration, and any person responsible for the payment of any amount by way of remuneration to any person under the provisions of any law or out of public funds (including the funds of any provincial council or any administration or undertaking of the State) or out of funds voted by Parliament or a provincial council".

14 See the definition of "resident" in $s 1$ of the ITA.

15 "Remuneration" is defined in par 1 of the Fourth Schedule as "any amount of income which is paid or is payable to any person by way of any salary, leave pay, wage, overtime pay, bonus, gratuity, commission, fee, emolument, pension, superannuation allowance, retiring allowance or stipend, whether in cash or otherwise and whether or not in respect of services rendered, including ...". The definition of "remuneration" expressly excludes from its ambit, inter alia, certain pension monies, disability grants, and earnings of a qualifying independent contractor. For the distinction between the terms "paid" and "payable", see Singh v CSARS 2003 (4) SA 520 (SCA) par 52.

16 Although the definition of "employee" in par 1 of the Fourth Schedule does not expressly exclude a qualifying independent contractor from its ambit, it is excluded by necessary implication. This is so by reason that an employee is defined to mean a person earning "remuneration" (as defined).

17 The "authority" envisioned in par 2(1) of the Fourth Schedule is catered for in par 11 thereof.

18 In this context, "or" has a disjunctive effect. This is unlike the conjunctive word "and". See Master Currency (Pty) Ltd v CSARS 2014 (6) SA 66 (SCA) par 15. In the present context, "or" distinguishes "deduct" from "withhold". Therefore, it follows that these words bear separate meanings for purposes of par 2(1). For a useful summary of the principles of statutory interpretation, see Chisuse v Director-General, Department of Home Affairs 2020 (6) SA 14 (CC) par 46-58.

19 S 156 of the TAA defines "withholding agent" to mean "a person who must under a tax Act withhold an amount of tax and pay it to SARS". The ITA is encompassed by the term "tax Act" as defined in $\mathrm{s} 1$ of the TAA.

20 See par 14(2) of the Fourth Schedule in the ITA.

21 See Mohamed $v$ Ally 1999 (2) SA 42 (SCA) 48. 
first, paragraph 3(1) effectively providing that PAYE is a first charge against remuneration; secondly, by paragraph $3(2)$ providing that the obligations in paragraph 2(1) of the Fourth Schedule

"shall apply ... notwithstanding the provisions of any law which provide that any such amount shall not be reduced or shall not be subject to attachment".

Accordingly, an employer's duty under paragraph $2(1)$ is absolute. The view expressed here is consistent with paragraph 3(1) stating that an employer's duty to withhold or deduct PAYE

"shall not be reduced or extinguished by reason of the fact that the employer has a right or is otherwise than in terms of any law under an obligation to deduct or withhold any other amount from the employees' remuneration". ${ }^{22}$

Paragraph 6(1) of the Fourth Schedule of the ITA, read with section 213(1) of the TAA, provide that an employer who fails to comply with paragraph 2(1) referred to above is liable to pay a percentage-based penalty equal to ten per cent of the unpaid tax. If non-compliance is tantamount to an "understatement" or a "substantial understatement", ${ }^{23}$ within the meanings of these terms in section 221 of the TAA, then, under section 222(1), an employer must pay an understatement penalty by reason of any "prejudice"24 caused. A penalty is imposed by SARS issuing a penalty assessment under section 214 of the TAA.

22 However, in terms of par 2(1A), the duty to deduct or withhold PAYE does not apply to "any year of assessment of a company or trust solely by virtue of paragraph (c) of the definition of 'personal service provider' where the company or trust has in respect of such year of assessment provided that person with an affidavit or solemn declaration stating that the relevant paragraph does not apply and that person relied on that affidavit or declaration in good faith".

23 "Understatement penalty" as defined means "a case where the prejudice to SARS or the fiscus exceeds the greater of five per cent of the amount of 'tax' properly chargeable or refundable under a tax Act for the relevant tax period, or R1 000 000".

24 For a conceptualisation of prejudice in s 221 of the TAA, see ITC 1934 supra par 43-45. In casu, the court held that "prejudice" includes SARS performing an audit that leads to the uncovering of unlawful behaviour by a taxpayer. The correctness of this view is, it is submitted, questionable. In terms of $s 3(1)$ of the TAA, SARS is responsible for the administration of tax Acts. Section 3(2)(a) to (I) prescribes the responsibilities that comprise "administration of a tax Act". It includes to "enforce SARS' powers and duties under a tax Act to ensure that an obligation imposed by or under a tax Act is complied with" (s 3(2) $(g)$ ). Under s 40 of the TAA, "SARS may select a person for inspection, verification or audit on the basis of any consideration relevant for the proper administration of a tax Act, including on a random or a risk assessment basis". Thus, conducting an audit is no more than SARS fulfilling its obligations to administer taxes efficiently and effectively. The performance of this function, coupled with the financial and human resources costs associated therewith, ought not to be "prejudice" within the meaning of this term in the context of the definition of understatement in s 221 of the TAA. In that context, prejudice entails acts or omissions by a taxpayer or representative taxpayer in violation of duties arising from a tax statute and which conduct adversely affects the interests of SARS, or the fiscus. Prejudice ought not to include actions by SARS in the execution of its statutory role which, of necessity, involves the incurrence of costs. For purposes of an understatement, a causal nexus must exist between, on the one hand, the offending conduct by a taxpayer and, on the other, the prejudice endured by SARS or the fiscus. See Department of Land Affairs $v$ Goedgelegen Tropical Fruits (Pty) Ltd 2007 (6) SA 199 (CC) par 50 (and the authorities cited there at fn 45). 
The percentage-based penalty referred to in the preceding paragraph falls squarely within the definition of an "administrative noncompliance penalty" in section 208 of the TAA. Even though they may be compensatory in effect, such penalties and understatement penalties are "punishment" 25 that may be imposed for non-compliance with employees' tax obligations arising from the ITA. These are not criminal sanctions. Rather, they are purely administrative in nature. Apart from the imposition of these administrative penalties, the legislature also catered for the imposition of criminal sanctions for breaches of an employer's PAYE obligations.

To this end, paragraph 30(1) of the Fourth Schedule of the ITA is instructive. The relevant part thereof reads:

"Any person who wilfully and without just cause- ...

(b) uses or applies any amount deducted or withheld by him by way of employees' tax for purposes other than the payment of such amount to the Commissioner; ...

shall be guilty of an offence and liable on conviction to a fine or to imprisonment for a period not exceeding 12 months."

In addition to administrative penalties and statutory criminal offences provided for by the ITA as read with the TAA, employers may also be prosecuted for common-law crimes (such as theft or fraud involving employees' tax collected but unpaid to SARS). ${ }^{26}$

The foregoing practical realities raise the critical question of law forming the subject of research in this article: can a taxpayer raise the defence of double jeopardy in response to a charge in respect of a common-law or statutory offence in circumstances where, as employer, it has already paid an administrative non-compliance or understatement penalty imposed by SARS under the TAA arising from the same or substantially identical facts that give rise to the criminal charge?

A case law survey reveals that, although some judicial dicta exist that grapple with this vexed issue, it has not as yet been dealt with in relation to the TAA, and nor has it been authoritatively decided by either the Supreme Court of Appeal (SCA) or the Constitutional Court (CC). There is also a dearth of published academic writings canvassing this important constitutional issue. Accordingly, this article carries the potential to make a meaningful contribution to the discourse pertaining to this subject.

\section{ROADMAP OF THE DISCUSSION}

The ensuing discussion is divided into two main parts. In the first part, the plea of autrefois acquit or autrefois convict will be discussed with reference to its origins and application in light of the common law, the Constitution and the Criminal Procedure Act $^{27}$ (CPA). This discussion aims to lay a firm foundation for the argument that South African employers and taxpayers

\footnotetext{
ITC 1934 supra par 41; Mr X v CSARS TC (unreported) 20200327 Case no 13720 par 29. 26 See Grayston Technology Investment (Pty) Ltd v S 2016 (4) All SA 908 (GJ) par 95-101.

$27 \quad 51$ of 1977.
} 
generally are entitled, as any other accused, to the equal benefit and protection of the defence embodied in the double-jeopardy rule. In the second part, with reference to relevant case law, the limits to the application of the double-jeopardy rule are discussed. In this part, the legal basis is laid for the central hypothesis of this article, namely that the rule against double jeopardy may be successfully invoked by an accused employer in circumstances where it had already paid an administrative penalty whose fairness was, despite appeal by the taxpayer, approved by the Tax Board or the Tax Court consequent on the same, or substantially the same, misconduct for which the taxpayer is charged criminally. Finally, the conclusion distils the thrust of the key submissions made in the ensuing discussion.

\section{THE DOUBLE-JEOPARDY RULE AS APPLIED IN SOUTH AFRICA (SA)}

\section{Common-law origins and constitutional status}

Double jeopardy is universally adopted in legal systems across the world, including at international law. ${ }^{28}$ However, the rules governing double jeopardy vary from jurisdiction to jurisdiction. In general terms, the doublejeopardy rule provides that no one may be punished twice for the same offence. ${ }^{29}$ Therefore, this rule prevents the re-prosecution of persons for the same matter. ${ }^{30}$ As such, it promotes reasonableness and fairness. Although this rule is mainly applied in the field of criminal law, in SA, this procedural rule applies also in some civil contexts (such as at employee disciplinary hearings in labour law). ${ }^{31}$

Double jeopardy is grounded on the principle of finality engrained in the doctrine of res judicata. This doctrine is predicated on the need for avoiding un-ending litigation by re-opening or re-trying cases. ${ }^{32}$ Accordingly, double jeopardy serves, on the one hand, to restrain the prosecutorial powers of the State with its significant financial and human resources and, on the other, to protect subjects from harassment through abuse of the criminal justice process. ${ }^{33}$ In so doing, double jeopardy protects individuals against continual

28 For e.g., see article 14(7) of the International Convention on Civil and Political Rights, 1966 and article 4(1) of Protocol 7 to the European Convention on Human Rights, 1950. See S v Basson 2007 (1) SACR 566 (CC) par 252-253.

29 Lelaka v S SCA (unreported) 2015-11-26 Case no 409/15 par 6.

30 The "same offence" is not confined to an "identical offence". See $R v$ Constance 1960 (4) SA 629 (A) 635B-636D.

31 In Mahlakoane v South African Revenue Service 2018 (39) ILJ 1034 (LAC) par 27, the court held: "The principle of 'double jeopardy' has, as its heart, fairness and this rule or principle simply entails that an employee cannot, generally, be charged again with the same misconduct that he or she was either found guilty or not guilty of. However, there are instances where breaches of this rule or principle can be condoned. The paramount consideration, however, is fairness to both sides."

32 See Thwala v S 2019 (1) BCLR 156 (CC) par 10.

33 Jordaan "Appeal by the Prosecution and the Right of the Accused to be Protected Against Double Jeopardy: A Comparative Perspective" 199932 Comparative and International Law Journal of Southern Africa 12-3. Also, see S v Basson 2005 (1) SA 171 (CC) par 61, 66. 
anxiety, embarrassment, ordeal and expense caused by repeated prosecutions at the insistence of the State and its officials. ${ }^{34}$

In SA, double jeopardy became part of the law via the common law. It stems from the English law maxim, nemo debet bis vexari pro una et eadem causa (no person shall be vexed twice for the same cause of action). This, in turn, is derived from the Roman law, exceptio rei judicatae. ${ }^{35}$ As a result, historically in SA, an accused convicted, acquitted or discharged at a criminal trial has, generally, been regarded as being in legal jeopardy. Therefore, the State was precluded from later charging the accused with the same offence, or with what is, in effect, the same offence..$^{36}$ In this context, it is an accepted principle that an "offence embraces both the facts which constitute the crime and the legal characteristics which make it an offence". ${ }^{37}$

The common-law rule against double jeopardy acquired statutory recognition in section 106(1)(c) and (d) of the CPA. ${ }^{38}$ Later, it acquired the imprimatur of the Constitution when it was entrenched in section $35(3)(m)$ of the BoR as a fundamental right of an accused. This subsection reads:

"Every accused person has a right to a fair trial, which includes the right- ... not to be tried for an offence in respect of an act or omission for which that person has previously been either acquitted or convicted."

Section 9(1) of the Constitution entrenches the right of all persons to equality. It reads: "Everyone is equal before the law and has the right to equal protection and benefit of the law." This provision is reinforced by section 9(2) of the Constitution, which reads: "Equality includes the full and equal enjoyment of all rights and freedoms." Although the Constitution does not expressly refer to taxpayers, the rights in the BoR apply to all natural and juristic persons qua taxpayers. ${ }^{39}$ Also, SARS is an organ of state for constitutional purposes and, under s 8(1) of the Constitution, it is bound by the BoR. Accordingly, the fair-trial rights of every accused in a criminal court include the right entrenched in section $35(3)(\mathrm{m})$ of the Constitution.

Denying any accused the benefits stemming from s $35(3)(m)$ would create unequal treatment of persons. Such inequality in the criminal justice system would be antithetical to the values of equality, the achievement of equality, and the advancement of human rights and freedoms, all of which are

\footnotetext{
Green v US 1957355 US 184 187-188.

$S v$ Moodie 1962 (1) SA 587 (A) 596C.

$S v$ Ndou 1971 (1) SA 668 (A) 676C-E.

37 Connelly v Director of Public Prosecutions (DPP) 1964 (2) All ER 401 433G-H (quoted with approval in Lelaka $v$ S supra par 6).

38 The relevant extract from s 106(1) reads: "When an accused pleads to a charge, he may plead ... (c) that he has already been convicted of the offence with which he is charged; or (d) that he has already been acquitted of the offence with which he is charged." These provisions apply in conjunction with s 336 of the CPA. By virtue of this provision, when offending conduct may sustain a charge under the common law and statute, the prosecution can, unless a contrary indication appears from the particular statute, elect to charge an accused in terms of one of these sources of law, but not both. See $S$ v Mostert 2010 (1) SACR 223 (SCA) par 18-19.

39 Moosa The 1996 Constitution and the Tax Administration Act 28 of 2011: Balancing Efficient and Effective Tax Administration With Taxpayers' Rights (doctoral thesis, University of the Western Cape) 2016 184-187.
} 
democratic values entrenched in the Constitution. ${ }^{40}$ Therefore, the plea of autrefois convict or acquit ought to be available to every accused when pleading to a charge of any nature, irrespective of whether the relevant offence stems from legislation or the common law.

\section{Relevant considerations when double jeopardy is asserted}

When pleading double jeopardy, an accused is "deemed to demand that the issues raised by the plea be tried". ${ }^{41}$ To establish the facts supporting such a plea, the accused bears the burden to prove all relevant particulars of the prior case in which he or she was convicted or acquitted. ${ }^{42}$ These particulars can be presented through oral evidence or by documentary proof (such as a certified copy of the prior judgment or a transcript of the prior proceeding), or by both forms of evidence. If a plea of autrefois convict or acquit is upheld, then the prosecution of the case where this plea is raised is barred, but then only as regards the offence(s) to which the plea relates. ${ }^{43}$

A plea of autrefois convict or acquit in a second prosecution only protects an accused if "he or she was in jeopardy of conviction in the first". ${ }^{4}$ An accused may succeed with this plea provided that certain legal requirements are met. ${ }^{45}$ First, the prior trial of the accused must have been by a competent court; 46 secondly, the substance of the present matter must be the same as, or substantially identical ${ }^{47}$ to, that which was previously adjudicated; thirdly, the earlier judgment must be intended ${ }^{48}$ to be final as concerns guilt or innocence of the accused on the merits, either in law or on the facts; ${ }^{49}$ and fourthly, the earlier case must relate to a charge on which a

Moosa Taxpayers' Rights 223-226.

$S 108$ of the CPA.

$42 \quad R v$ Matengeni 1969 (4) SA 392 (R) 393H-394C.

43 Lansdown, Hoal and Lansdown South African Criminal Law and Procedure vol 1 (1957) 366-367.

$44 \quad S v$ Basson 2007 (1) SACR 566 (CC) par 254.

45 For a discussion of the various legal requirements, see Lansdown et al South African Criminal Law and Procedure 367-368. Also, see R v Manasewitz 1933 AD 165 173-174.

46 Hiemstra Suid-Afrikaanse Strafproses 5ed (1993) 260. Also, see S v Odendaal 1995 (2) SACR 449 (T) 451.

47 The test for substantial identity is "whether the evidence necessary to support the second indictment would have been sufficient to procure a legal conviction upon the first indictment" ( $S \vee$ Ndou supra 680F) or "an offence for which on the first charge there could be a conviction" (per Lord Morris in Connelly v DPP supra 433G-H).

48 To determine the existence of any such intention requires a proper interpretation of the court's judgment and order. For the applicable interpretive rules, see Eke $v$ Parsons 2016 (3) SA 37 (CC) par 29-30; Natal Joint Municipal Pension Fund v Endumeni Municipality 2012 (4) SA 593 (SCA) par 18-22.

49 Sayed v S 2018 (1) SACR 185 (SCA) par 25. In S v Basson 2007 (1) SACR 566 (CC) par 254, it was held: "The requirement that the previous acquittal must have been on the merits, or to put it differently, that the accused must have been in jeopardy of conviction, means that, if the previous prosecution was vitiated by irregularity, then it cannot found a plea of autrefois acquit in a subsequent prosecution. That is because the accused was not acquitted on the merits and was never in jeopardy of conviction because the proceedings were vitiated by irregularity." 
valid judgment could be entered in favour of, or against, the accused. 50 Accordingly, for purposes of the application of the rule against double jeopardy, it is irrelevant whether a criminal charge stems from the common law or a statutory provision creating an offence.

The rule against double jeopardy is not inflexible or absolute. Its operation is subject to certain exceptions, where appropriate. For example, in criminal law, double jeopardy is no bar to a prosecution on a heavier charge (such as murder or culpable homicide) after an accused was previously convicted or acquitted of a lighter offence stemming from the same conduct (such as assault). In this instance, the victim's death is a material "new fact" 51 that would justify deviation from the double-jeopardy rule engrained in section $35(3)(m)$ of the Constitution.

Similarly, in labour law, provided "it is, in all the circumstances, fair to do so", ${ }^{52}$ an employee may be subjected to a second disciplinary hearing on the same issue for which he or she has been found guilty or acquitted. Consequently, in MEC for Finance, KwaZulu-Natal v Dorkin NO,53 the appeal court held that, having regard to the gravity of the offences for which the employee was found guilty, "exceptional circumstances" existed that made it fair to permit the employer to subject its employee to a repeat hearing through proceedings in the Labour Court.

\section{LIMITS TO DOUBLE JEOPARDY: DOES IT APPLY WHEN SARS IMPOSES ADMINISTRATIVE PENALTIES?}

The discussion under heading 4 reveals that, to succeed with a plea of autrefois acquit or convict, an accused employer in a criminal trial must prove he was acquitted or convicted by a competent court of law for the same (or substantially the same) offence. This requirement was dealt with in $S v$ Odendaal. ${ }^{54}$ In casu, the accused was convicted in a lower court under certain Road Traffic Regulations of 1990 for having failed timeously to register and license a trailer. Prior to his prosecution, the accused paid the prescribed penalty ("boete") to the traffic authority in accordance with regulation $27(1)$. In terms of regulation $27(2)$, this payment did not absolve the accused, as owner, of criminal liability for failing to register and license the relevant trailer timeously. As a result, by law, he was prosecuted for his failure. At his trial arising from the same facts that led to the payment of a penalty, the accused pleaded that the rule against double jeopardy precluded the prosecution undertaken against him. This plea was dismissed, and the accused was convicted of the offence.

50 If a superior court, on appeal, quashes an indictment on the basis that it was bad ab initio, then the accused cannot rely on double jeopardy in a later criminal trial because he or she was never legally in jeopardy. See $R v$ Manasewitz supra 174.

51 S v Ndou supra 676C.

52 BMW (South Africa) (Pty) Ltd v Van der Walt 2000 (21) ILJ 113 (LAC) par 12

532008 (6) BLLR 540 (LAC) par 14.

54 Supra. 
This decision was confirmed on review by Southwood J. He held the penalty paid under regulation 27(1) was administrative in nature. It was not imposed by a court of law pursuant to a finding of guilt after a prosecution. Southwood $\mathrm{J}$ held that this was critical to a determination of whether the accused was protected by the rule against double jeopardy, which at all material times formed part of the suite of fair-trial rights accruing to the accused under the interim Constitution, 1993. Southwood J held that since payment of the penalty did not occur after a guilty verdict against the accused by a competent court of law, the rule against double jeopardy did not protect the accused against subsequent prosecution for the same conduct that led to the payment of the administrative penalty in the first place.

This decision is important in the context of tax administration. As explained above, an employer who defaults in his employees' tax obligations may suffer an administrative non-compliance penalty or understatement penalty imposed by SARS through a penalty assessment. Despite the penal nature of these impositions, based on the aforementioned ratio decidendi emerging from $S \vee$ Odendaal, payment by an accused employer of an administrative penalty would not preclude a subsequent prosecution for a statutory crime or common-law offence arising from the same misconduct that led to the penalty being imposed against the taxpayer in the first place. In other words, at a criminal trial, the taxpayer would, in these circumstances, not have recourse to the fundamental right accorded by section $35(3)(m)$ of the Constitution. For the reasons that follow, it is submitted that this is not the legal cum constitutional position that ought to apply in criminal cases where an administrative penalty imposed by SARS was paid by a taxpayer after the penalty was, in whole or in part, upheld by the Tax Board or Tax Court.

An administrative non-compliance penalty and understatement penalty imposed by SARS is provisional only. In terms of sections 220 and 224 of the TAA, they are respectively subject to appeal to the Tax Board or Tax Court. Therefore, these statutory institutions are the ultimate arbiters of the fairness of a penalty imposed against a taxpayer. ${ }^{55}$ While the Tax Board and Tax Court are not courts in the judicial hierarchy under section 166 of the Constitution, they are "specialist tribunals" 56 created by the TAA to perform an adjudicative role in tax disputes. A taxpayer who pays a penalty approved by the Tax Board or Tax Court does so in accordance with a decision by a competent administrative adjudicative authority that is properly established by law.

Accordingly, for purposes of the double-jeopardy rule, decisions of the Tax Board and Tax Court ought to carry the same weight as that of a competent court of law. If so, then a taxpayer ought to be entitled, as a matter of legal principle, to plead double jeopardy against a criminal charge in relation to a statutory or common-law offence arising from the same or

55 CSARS v Hawker Air Services (Pty) Ltd; CSARS v Hawker Aviation Partnership 2006 (4) SA 292 (SCA) par 14

56 Metcash Trading Ltd $v$ CSARS supra par 32. While the Tax Board is an administrative tribunal, the Tax Court is more appropriately described as a "court of revision" (see Africa Cash \& Carry v CSARS 2020 (2) SA 19 (SCA) par 52). 
substantially the same facts that led to the imposition of an administrative penalty that has been paid by the taxpayer prior to the institution of the criminal case but only after it was approved by a duly constituted Tax Board or Tax Court, as the case may be. Authority for this proposition is found in the obiter dictum in Grayston. ${ }^{57}$

In casu, it was held that section 35(3) $(m)$ of the Constitution "transcends the confines of purely criminal procedure" and provides "a constitutional safeguard against double jeopardy irrespective of whether the forum empowered to impose the sanction is a criminal court, a civil court or an administrative tribunal". ${ }^{58}$ The court held that the doctrine of res judicata, which underpins double jeopardy, as well as the principles of justice and reasonableness underpinning the Constitution and the right to just administrative action in section 33 of the Constitution, give practical expression to the same legal sentiment, namely that "a person should be protected from being repeatedly brought to answer in respect of the same conduct", ${ }^{59}$ regardless of the forum where such person is brought to answer for his conduct.

Support for the court's conclusion that double jeopardy ought to apply in cases where punishment in the form of a civil (administrative) penalty was authorised by a tribunal that is not a court of law was found in international and foreign law. This was possible owing to the interpretive directives in section $39(1)(b)$ and $(c)$ of the Constitution. To this end, the court considered the decision in Han $v$ Commissioner of Customs \& Excise and Similar Cases. ${ }^{60}$ This is an English case that concerned the imposition of civil penalties by the customs authority owing to the taxpayer evading payment of VAT for which there also existed a parallel scheme of statutory offences.

In Han, the court held that, in determining whether a person had been subjected to a "criminal charge", as that term is used in Article 6 of the European Convention for the Protection of Human Rights and Fundamental Freedoms, due regard must be given to the "substantive" rather than "formal" conception of the term "charge". To do so "impels the Court to look behind the appearances and examine the realities of the procedure in question in order to determine whether there has been a "charge" within the meaning of Article 6". ${ }^{61}$ In this regard, three factors, to be considered cumulatively, were identified as relevant to whether double jeopardy applies to an accused person for purposes of Article 6 of the European Convention. These are: (i) the classification of the relevant proceedings in the applicable domestic law; (ii) the nature of the offence charged; and (iii) the nature and degree of severity of the penalty that the accused risked incurring if convicted.

For purposes of deciding the appeal in Grayston, it was unnecessary for the court, on the facts, to decide whether, in light of the prior imposition of civil penalties against the appellant taxpayers, double jeopardy precluded

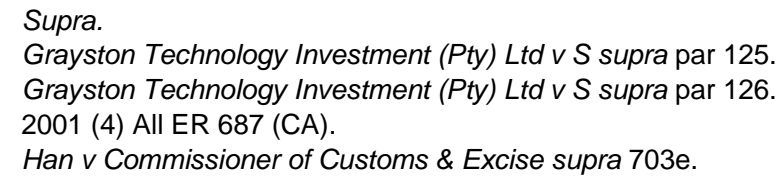


the statutory charges for which they were convicted. This is so because, first, the appellants accepted that they could be convicted and sentenced on the criminal charges, despite the civil penalties. Therefore, they did not raise the plea of autrefois convict. Secondly, "the evidence before the court did not indicate what administrative penalties were imposed, nor could they be determined because the interest portion of the judgment debts was not disclosed". ${ }^{62}$ Consequently, on the specific facts before the appellate court, double jeopardy did not apply. Therefore, the views expressed by the court on the question of the application of double jeopardy are obiter.

\section{CONCLUSION}

This article shows that the double-jeopardy rule is, under the Constitution, an integral part of the right of every accused person to a fair trial. Consequently, every delinquent employer who fails to comply with its employees' tax obligations is entitled to plead double jeopardy. For this defence to succeed, the relevant legal requirements must be met. This article demonstrates that there is now judicial authority for the proposition that an accused employer may successfully invoke double jeopardy even if the prior punishment or acquittal stems from non-criminal proceedings before a specialist tribunal (such as, the Tax Board or Tax Court). This approach is beneficial to employers and ought to be embraced as enlightened and consonant with the spirit of the BoR.

However, the operation of double jeopardy in circumstances where an accused employer has paid a civil penalty arising from the same or similar facts appears to conflict with the Legislature's intention to impose criminal and civil sanctions for certain violations of obligations arising under fiscal legislation. The application of double jeopardy in such circumstances may well undermine the deterrent effect sought to be achieved by the Legislature catering for civil and criminal sanctions. An equitable balance ought, therefore, to be struck between, on the one hand, the right of an accused employer to a fair trial and, on the other hand, society's interest in ensuring that every taxpayer pays a fair share of tax timeously. Consequently, there may be instances where an employer may justifiably be subjected to a civil penalty and criminal sanction for failing to pay employees' tax to SARS, whether timeously or at all. This was recognised in Grayston, where the court held that "[d]ouble jeopardy cannot arise every time two different tribunals consider holding the same person responsible for some act or omission". ${ }^{63}$ However, no hard-and-fast rules can be laid down in advance as to the, presumably rare, circumstances where double jeopardy may not be successfully invoked. Each case must be decided on its own facts.

Grayston Technology Investment (Pty) Ltd v S supra par 124.

63 Grayston Technology Investment (Pty) Ltd v S supra par 128. 